\title{
DETERMINANTS OF BANK PROFITABILITY: CASE OF LATVIA
}

\author{
Dace Krumina $^{1}$, Ilona Lejniece ${ }^{2}$, Viktorija Skvarciany ${ }^{3}$ \\ ${ }^{l}$ EKA University of Applied Sciences, Riga, Latvia, dace.kampara@gmail.com \\ ${ }^{2}$ EKA University of Applied Sciences, Riga, Latvia, lejniece.ilona@gmail.com \\ ${ }^{3}$ Vilnius Gediminas Technical University,Vilnius, Lithuania,viktorija.skvarciany@vgtu.lt
}

\begin{abstract}
Research purpose. The goal of the current paper is to investigate the impact of internal factors on bank performance. All the performance indicators and explanatory factors have been distinguished from the scientific literature.

Design/methodology/approach. To investigate if there was an effect of the distinguishing factors on Latvian banks' performance, correlation-regression analysis was applied. To test the developed models' accuracy, determination coefficient, Durbin-Watson coefficient, variance inflation factor (VIF), Cook's distance and p-value were computed.

Findings. The findings revealed that there was a relationship between all the dependent and independent factors, except return on assets (ROA) and return on equity (ROE). ROA has a significant positive relationship only with net commission income, and ROE, with net interest margin and net commission income. Moreover, two regression models were developed and showed that total assets and number of automated teller machines (ATMs) affect the profitability, represented by earnings before interest, taxes, depreciation, and amortization (EBIDTA) and bank value.

Originality/value/practical implications. The current findings contribute to the scientific literature dealing with commercial banks' performance issue and could be used by the banks to develop strategies for maximising profitability.
\end{abstract}

Keywords: Bank performance; performance factors; banking sector; commercial banks.

JEL codes: G21

\section{Introduction}

Commercial banks' performance has been investigated in a wide range of studies (Haris et al., 2019; Barra \& Zotti, 2019; Fang et al., 2019; Doku et al., 2019; Yang et al., 2019), but despite that, it still remains one of the core scientific questions. Many researchers analyse performance through profitability and raise the research problem on how to enhance the profitability of commercial banks (Adnan, 2019; Titko et al., 2016; Athanasoglou et al., 2008; Dietrich \& Wanzenried, 2011; Keliuotytė-Staniulènienè \& Smolskyte, 2019). There is a viewpoint that bank profitability increases the level of economic stability (Neves et al., 2020). Hence, it is vital for commercial banks and for the countries they are located in to raise the profitability of those banks, as a stable banking sector could have an impact on the well-being of society and is an essential indicator of the development of the national economy.

To maximise the profitability of commercial banks, it is necessary to investigate the factors affecting it. Knowing those factors influences the development of the banking sector (Dogan \& Eksi, 2020). Scholars analyse different factors of bank profitability, including internal and external factors (Batten \& Vo, 2019; Utomo \& Anggono, 2020; Abate \& Mesfin, 2019; Dang \& Vong, 2019; Adelopo et al., 2018). However, it is believed that different groups of factors should be analysed separately. Hence, the current study aims at investigating the impact of internal factors on performance of Latvian banks. 
The research question is "what internal factors affect bank performance in Latvia?" Internal factors are proxied by bank-specific measures. Indices describing customer base, balance sheet items and income statement items were regressed against bank performance ratios. SPSS software was used for data processing.

\section{Literature review}

Currently, there are 13 banks in Latvia, and the major part of the market is occupied by three banks, that is, Swedbank (37\%), SEB bank (25\%), Citadele bank (22\%).

The first stage of the research is an in-depth literature analysis to select the appropriate factors and associated indicators. First of all, it is necessary to determine the factors by which profitability is measured. The most widely used profitability indicators are return on assets (ROA) and return on equity (ROE) (Boussaada \& Hakimi, 2020; Domanovic et al., 2018; Ndlovu \& Alagidede, 2018; Titko et al., 2014). Another frequently used bank profitability measure is net interest margin (NIM) (Adelopo et al., 2018; Angori et al., 2019; Dinc, 2018; Gupta \& Mahakud, 2020; Haris et al., 2019). There are scholars measuring profitability via bank value. Fouche et al. (2008) claim that the value of bank could be maximised via different factors, such as optimal choices of loan rate and supply, provisions for deposit withdrawals and bank profitability. Elsas et al. (2010) argue that higher bank profitability translates into higher market valuations, which, in turn, has a positive influence on bank value. Consequently, it could be stated that profitability and bank value move into one direction, and because of that, in the current paper, the value is selected as the indicator of profitability. Another factor measuring bank profitability is bank operating profit, as it is described as bank profitability before taking into account taxes and interest. Another profitability indicator that is believed to be one of the most important is earnings before interest, taxes, depreciation and amortization (EBITDA), despite the fact that it is has been analysed only by few scholars (Królikowska \& Sierpińska-Sawicz, 2016; Neerza \& Tripathi, 2019). Asset turnover is treated as a bank profitability measure as well (Duho et al., 2020; Neerza \& Tripathi, 2019). All in all, there are seven dependent variables in the study representing bank profitability, and they are as follows: ROA, ROE, NIM, bank value, bank operating profit, EBIDTA and asset turnover.

The second step of the literature review is to determine the internal factors that could have an impact on profitability indicators. As it was mentioned in the introduction part, the current study focuses only on the internal factors. The first factor that should be mentioned as the independent one is the bank's assets. Owusu and Alhassan (2020) state that assets are the item that could generate the highest return on profitability. Undoubtedly, the number of customers is also a vital factor, as it directly influences the profitability of a commercial bank. There are two main types of bank customers - private and legal customers. Thus, the current study seeks to investigate if the total number of customers has an impact on profitability, as well as private and legal customers, could be considered separately as influencing factors. Authors researching bank profitability issues claim that number of automated teller machines (ATMs) could improve profitability (Akhisar et al., 2015; Jegede, 2014; Le \& Ngo, 2020; Ramila \& Gurusamy, 2016; Salimi et al., 2013; Turkoglu \& Genevois, 2017). In line with ATMs, the number of payment cards could play a vital role in maximising bank's profitability, as they are used to reach customers via a point of sale (POS) and ATMs; hence, the number of payment cards is considered to be another independent variable (Hamdi et al., 2017; Le \& Ngo, 2020). Another factor that should be mentioned is the number of customer service centres. In fact, the great part of services are available online; still, it is important for clients to have the ability to solve the arising problems face to face. Hence, this factor is considered as the item that could have an impact on profitability. As online services have been mentioned, one more factor influencing profitability is internet banking users. Actually, the commercial bank provides online services not only for their work optimisation, but it also helps to reach new customers (Onay et al., 2018), which, in turn, helps to boost the profitability. Chen (2020) has also investigated bank profitability issues and stated that there is a relationship between loans and deposits and bank profitability; consequently, these items are also included in the current study. Apart from that, there is a large number of pieces of research investigating net interest income as a possible factor of profitability (Altavilla et al., 2018; Babajide et al., 2020; Borio et al., 2017). Naruševičius (2017) investigates the relationship between bank profitability and net commission income; hence, this indicator is studied in the current paper as well. 
To sum up, seven dependent variables, representing a commercial bank's profitability, and 11 independent variables, describing the factors that could increase the profitability, were distinguished. To check if the influence exists, the hypotheses have been raised. The tested relationships and impacts are depicted in Figure 1.

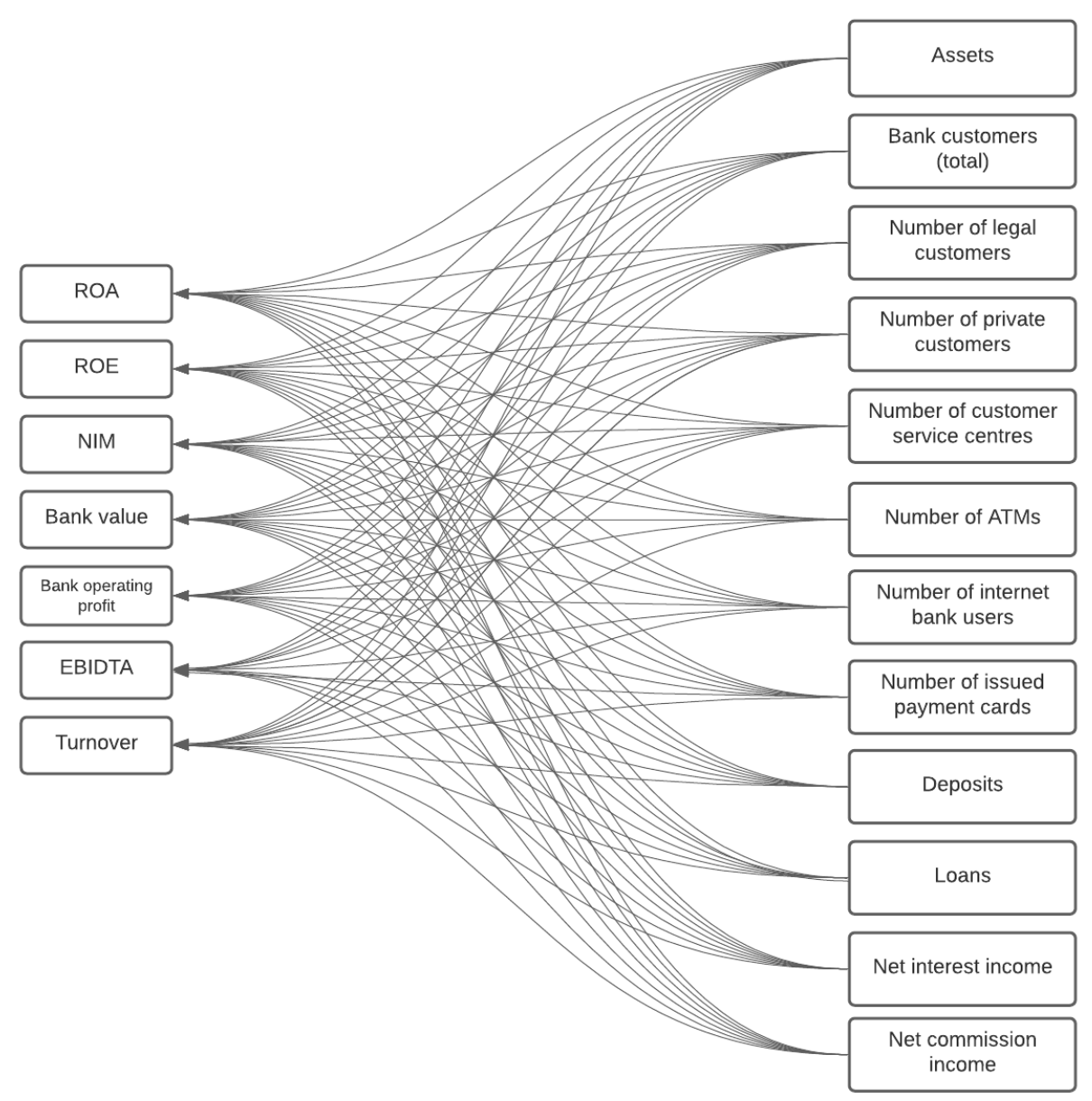

Fig. 1. Research model (Source: created by authors)

\section{Research methodology}

Before describing the selected methods, the variables used in the study are provided (see Table 1). It is worth mentioning that some of the variables were log-transformed to convert highly skewed variables into more approximately normal.

Table 1. Variables and their measures (source: authors' compilation)

\begin{tabular}{|c|c|c|}
\hline Variable & Measure & Notation \\
\hline \multirow{4}{*}{ Profitability } & Return on equity & ROE \\
\cline { 2 - 3 } & Return on assets & Value \\
\cline { 2 - 3 } & Bank value & OpProf \\
\cline { 2 - 3 } & Operating profit & EBIDTA \\
\cline { 2 - 3 } & EBITDA profitability & NIM \\
\cline { 2 - 3 } & Net interest margin & Turn \\
\cline { 2 - 3 } & Turnover & $\operatorname{lnTA}$ \\
\hline
\end{tabular}




\begin{tabular}{|c|c|c|}
\hline \multirow{2}{*}{ Customer base } & Total number of customers & NoC \\
\cline { 2 - 3 } & Number of legal customers & NoLC \\
\cline { 2 - 3 } & Number of private customers & BoPC \\
\hline Customers service centres (CSC) & Number of CSC & CSC \\
\hline ATM & Number of ATMs & ATM \\
\hline Internet bank & Number of internet bank users & IBank \\
\hline Payment cards & $\begin{array}{c}\text { Number of issued payment } \\
\text { cards }\end{array}$ & PC \\
\hline Deposits & Total deposits & $\operatorname{lnTD}$ \\
\hline Loans & Total loans & lnTL \\
\hline Bank interests & Net interest income & NII \\
\hline Bank commission fees & Net commission income & NCI \\
\hline
\end{tabular}

For relationship analysis, Pearson correlation coefficient was employed with significance level $\alpha=$ 0,05. After the correlation coefficients are calculated and tested for significance, the regression models were developed. All the models were tested for accuracy by using the following statistical parameters were used:

- Cook's $\left(D_{i}\right)$ distance was used to reveal if there were any outliers in the initial data. The observation is considered to be an outlier if $D_{i}>1$.

- The determination coefficient $\left(R^{2}\right)$ was employed to reveal which part of the dependent variable distribution could be described by the independent variables. The model is treated to be applicable if $R^{2}>0.25$.

- Variance inflation factor $(V I F)$ is used for identification of multicollinearity problem. The multicollinearity problem exists in case $V I F>5$.

- A p-value is used to find out if the correlation and regression coefficients are statistically significant. The coefficient significantly differs from zero in case $p$-value $<0.05$.

Calculations were made based on the data of five largest Latvian banks (Swedbanka, SEB banka, Citadele bank, BlueOrange bank and Rigensis bank). Period of 2012-2019 was covered.

\section{Research results}

The first step of research is correlation calculations between dependent and independent variables. The computed correlation coefficients are presented in Table 2.

Table 2. Correlation coefficients (source: authors' calculations)

\begin{tabular}{|c|c|c|c|c|c|c|c|c|c|c|c|c|}
\hline & $\ln T A$ & $\mathrm{NoC}$ & NoLC & NoPC & CSC & $A T M$ & Ibank & $P C$ & $L n T D$ & LnTL & NII & $N C I$ \\
\hline$R O E$ & 0.179 & 0.099 & 0.146 & 0.102 & -0.039 & 0.001 & 0.098 & -0.111 & 0.255 & -0.190 & 0.245 & $.371^{*}$ \\
\hline$p$-value & 0.270 & 0.541 & 0.367 & 0.530 & 0.812 & 0.993 & 0.546 & 0.501 & 0.113 & 0.246 & 0.128 & 0.018 \\
\hline$R O A$ & 0.237 & 0.135 & 0.193 & 0.132 & 0.088 & 0.228 & 0.165 & -0.137 & 0.297 & -0.089 & $.362^{*}$ & $.317^{*}$ \\
\hline$p$-value & 0.141 & 0.405 & 0.234 & 0.418 & 0.588 & 0.157 & 0.308 & 0.405 & 0.063 & 0.591 & 0.022 & 0.046 \\
\hline Value & $0.922^{* *}$ & $0.913^{* *}$ & $0.924^{* * *}$ & $0.899^{* *}$ & $0.909^{* * *}$ & $0.962^{* * *}$ & $0.940^{* *}$ & $0.890^{* *}$ & $0.891^{* *}$ & $0.930^{* *}$ & $0.899^{* * *}$ & $0.802^{* *}$ \\
\hline$p$-value & 0.000 & 0.000 & 0.000 & 0.000 & 0.000 & 0.000 & 0.000 & 0.000 & 0.000 & 0.000 & 0.000 & 0.000 \\
\hline OpProf & $0.862^{* *}$ & $0.832^{* *}$ & $0.862^{* *}$ & $0.822^{* *}$ & $0.780^{* * *}$ & $0.868^{* *}$ & $0.858^{* *}$ & $0.823^{* *}$ & $0.861^{* *}$ & $0.837^{\text {** }}$ & $0.847^{\text {** }}$ & $0.848^{* *}$ \\
\hline$p$-value & 0.000 & 0.000 & 0.000 & 0.000 & 0.000 & 0.000 & 0.000 & 0.000 & 0.000 & 0.000 & 0.000 & 0.000 \\
\hline EBITDA & $0.946^{* *}$ & $0.936^{* *}$ & $0.946^{* *}$ & $0.925^{* *}$ & $0.919^{* * *}$ & $0.962^{* *}$ & $0.959^{* * *}$ & $0.917^{* *}$ & $0.919^{* *}$ & $0.947^{* *}$ & $0.922^{* *}$ & $0.829^{* * *}$ \\
\hline$p$-value & 0.000 & 0.000 & 0.000 & 0.000 & \begin{tabular}{|l|}
0.000 \\
\end{tabular} & 0.000 & 0.000 & 0.000 & 0.000 & 0.000 & 0.000 & 0.000 \\
\hline NIM & $0.318^{*}$ & $0.331^{*}$ & $0.321^{*}$ & $0.328^{*}$ & $0.413^{* *}$ & $0.375^{*}$ & $0.337^{*}$ & 00.203 & $0.348^{*}$ & 00.241 & $0.522^{\text {*** }}$ & 00.134 \\
\hline$p$-value & 0.046 & 0.037 & 0.043 & 0.039 & 0.008 & 0.017 & 0.033 & 0.216 & 0.028 & 0.140 & 0.001 & 0.410 \\
\hline Turn & $0.998^{* *}$ & $0.984^{* *}$ & $0.985^{* *}$ & $0.979^{* *}$ & $0.913^{* * *}$ & $0.875^{* *}$ & $0.985^{\text {*** }}$ & $0.987^{* *}$ & $0.990^{* *}$ & $0.970^{* *}$ & $0.971^{* *}$ & $0.913^{* *}$ \\
\hline$p$-value & 0.000 & 0.000 & 0.000 & 0.000 & 0.000 & 0.000 & 0.000 & 0.000 & 0.000 & 0.000 & 0.000 & 0.000 \\
\hline
\end{tabular}


From Table 2, it could be seen that the most correlation coefficients significantly differ from zero, that is, the null hypothesis is rejected. However, ROA and ROE do not have a linear relationship with internal profitability factors. For ROA, there is only one statistically significant relationship, and for ROE - two. For other profitabilityproxy measures (Value, EBITDA, OpProfit, NIM and Turn), all the correlation coefficients are statistically significant.

From the developed regression equations, only two models met all the requirements and are considered to be significant. The Model 1's summary is presented in Table 3.

Table 3. Model 1 summary (source: authors' calculations)

\begin{tabular}{|c|c|c|c|c|c|c|}
\hline \multicolumn{7}{|c|}{ Model Summary } \\
\hline $\mathrm{R}$ & $\mathrm{R}^{2}$ & Adjusted $\mathrm{R}^{2}$ & Sig. & \multicolumn{3}{|c|}{ Durbin-Watson } \\
\hline 0.984 & 0.967 & 0.966 & 0.000 & \multicolumn{3}{|c|}{1.167} \\
\hline \multicolumn{7}{|c|}{ Coefficients } \\
\hline \multirow{2}{*}{ Model 1} & \multicolumn{2}{|c|}{ Unstandardised coefficients } & \multirow{2}{*}{$\mathrm{t}$} & \multirow{2}{*}{ Sig. } & \multicolumn{2}{|c|}{ Collinearity statistics } \\
\hline & $\mathrm{B}$ & Std. Error & & & Tolerance & VIF \\
\hline (Constant) & 5.576 & 0.784 & 7.108 & 0.000 & & \\
\hline $\ln T A$ & 0.411 & 0.060 & 6.842 & 0.000 & 0.219 & 4.569 \\
\hline ATM & 0.005 & 0.000 & 9.103 & 0.000 & 0.219 & 4.569 \\
\hline
\end{tabular}

As it could be seen from Table 3, the determination coefficient is very high and exceeds 95 per cent $\left(\mathrm{R}^{2}\right.$ $=0.967$ ), which means that the developed model explains 96.7 per cent of profitability variation. Profitability, in that case, is represented by EBIDTA (see equation (1)):

$$
E B I T D A=0.411 \times \ln T A+0.005 \times A T M
$$

From equation (1), we could see that total assets and the number of $A T M s$ are the variables that have an impact on a commercial bank's profitability. If the $A T M$ variable is fixed, then for each change of 1 unit in $\operatorname{lnTA}$ EBIDTA changes 0.411 units. If $\ln T A$ is fixed, then for each change of 1 unit in ATM, EBIDTA changes 0.005 units.

The results of the second developed model are presented in Table 4.

Table 4. Model 2 summary (source: authors' calculations)

\begin{tabular}{|c|c|c|c|c|c|c|}
\hline \multicolumn{7}{|c|}{ Model Summary } \\
\hline $\mathrm{R}$ & $\mathrm{R}^{2}$ & Adjusted $\mathrm{R}^{2}$ & Sig. & \multicolumn{3}{|c|}{ Durbin-Watson } \\
\hline 0.999 & 0.999 & 0.999 & 0.000 & \multicolumn{3}{|c|}{1.005} \\
\hline \multicolumn{7}{|c|}{ Coefficients } \\
\hline \multirow{2}{*}{ Model 2} & \multicolumn{2}{|c|}{ Unstandardised coefficients } & \multirow{2}{*}{$\mathrm{t}$} & \multirow{2}{*}{ Sig. } & \multicolumn{2}{|c|}{ Collinearity statistics } \\
\hline & $\mathrm{B}$ & Standard & & & Tolerance & VIF \\
\hline $\ln T A$ & 0.827 & 0.007 & 114.651 & 0.000 & 0.2398 & 2.514 \\
\hline$A T M$ & 0.001 & 0.000 & 2.813 & 0.000 & 0.398 & 2.514 \\
\hline
\end{tabular}

As it could be seen from Table 4, the determination coefficient is very high as in the previous model and exceeds 95 per cent $\left(R^{2}=0.999\right)$, which means that the developed model explains 99.9 per cent of commercial bank's value (see equation (2)):

$$
\text { Value }=0.827 \times \ln T A+0.001 \times A T M
$$

From equation (2), it could be stated that total assets and the number of ATMs are the variables that have an impact on a commercial bank's profitability represented by the bank's value. If the ATM variable is 
fixed, then for each change of 1 unit in $\ln T A$, Value changes 0.827 units. If $\ln T A$ is fixed, then for each change of 1 unit in ATM, Value changes 0.001 units.

The direct positive relationship between the volume of assets and bank performance is obvious. Assets (considering the traditional model of banking business in Latvia, loans) are the primary source for profit generation. In turn, the developed network of ATMs can also be a valuable income-generating factor, because of the commission fees. Not all the banks have ATMs in Latvia, and the customers are forced to use ATMs of other banks for money withdrawal. Cash transactions are still quite popular among Latvian citizens (according to Statista, more than 60 per cent of transaction in 2018). Thus, the banks with an expanded network of ATMs have a significant competitive advantage.

\section{Conclusions}

The goal of the current paper was to research the influence of internal factors on Latvian banking sector profitability. The profitability was represented by seven determinants, which were distinguished from the literature, and they are as follows: ROA, ROE, NIM, bank value, bank operating profit, EBIDTA and asset turnover. The mentioned seven variables were treated as dependent variables. The factors that could influence profitability were highlighted from the scientific literature as well and are as follows: total assets, the total number of customers, number of legal customers, number of private customers, number of customers service centres, number of ATMs, number of internet bank users, number of issued payment cards, total deposits, total loans, net interest income, net commission income.

First of all, the relationship between the factors was calculated. The results revealed that there was a statistically significant relationship between all the dependent and independent factors, except ROA and ROE. ROA has a significant linkage only with net commission income, and ROE - with NIM and net commission income.

Secondly, regression models were developed. It is worth noting that only two models were considered to be accurate according to the statistical parameters. The models show that total assets and number of ATMs have an effect on the profitability, represented by EBIDTA and bank value.

Construction of such predictive models is an attempt to help bank executives to properly manage bank performance, focusing on factors that may be underevaluated. The current research is limited with data of only five banks, and this shortage could be eliminated by expanding the database.

\section{References}

Abate, T. W., \& Mesfin, E. A. (2019). Factors affecting profitability of commercial banks in Ethiopia. International Journal of Research and Analytical Reviews, 6(1), 881-891.

Adelopo, I., Lloydking, R., \& Tauringana, V. (2018). Determinants of bank profitability before, during, and after the financial crisis. International Journal of Managerial Finance, 14(4), 378-398. https://doi.org/10.1108/IJMF07-2017-0148

Adnan, A. (2019). Does Market React To Tax Reduction News? an Empirical Study on Corporate Tax Reduction of Bangladesh in 2017-18. Business, Management and Education, 17(2), $286-308$. https://doi.org/10.3846/bme.2019.11274

Akhisar, İ., Tunay, K. B., \& Tunay, N. (2015). The Effects of Innovations on Bank Performance: The Case of Electronic Banking Services. Procedia - Social and Behavioral Sciences, 195, 369-375. https://doi.org/10.1016/j.sbspro.2015.06.336

Altavilla, C., Boucinha, M., \& Peydró, J.-L. (2018). Monetary Policy and Bank Profitability in a Low Interest Rate Environment. Economic Policy. https://doi.org/10.1093/epolic/eiy013

Angori, G., Aristei, D., \& Gallo, M. (2019). Determinants of Banks' Net Interest Margin: Evidence from the Euro Area during the Crisis and Post-Crisis Period. Sustainability, 11(14), 3785. https://doi.org/10.3390/su11143785

Athanasoglou, P.P., Brissimis, S.N. and Delis, M.D. (2008) Bank-specific, industry-specific and macroeconomic determinants of bank profitability. Journal of international financial Markets, Institutions and Money, 18(2), 121136. https://doi.org/10.1016/j.intfin.2006.07.001 
Babajide, A. A., Lawal, A. I., Amodu, L. O., Asaleye, A. J., Ewetan, O. O., Olokoyo, F. O., \& Matthew, O. A. (2020). Challenges of accountability in Nigeria: the role of deposit money bank. Journal of Money Laundering Control, 23(2), 477-492. https://doi.org/10.1108/JMLC-10-2019-0082

Barra, C., \& Zotti, R. (2019). bank performance, financial stability and market concentration: evidence from cooperative and non-cooperative banks. Annals of Public and Cooperative Economics, 90(1), 103-139.

Batten, J., \& Vo, X. V. (2019). Determinants of bank profitability-Evidence from Vietnam. Emerging Markets Finance and Trade, 55(6), 1417-1428.

Borio, C., Gambacorta, L., \& Hofmann, B. (2017). The influence of monetary policy on bank profitability. International Finance, 20(1), 48-63. https://doi.org/10.1111/infi.12104

Boussaada, R., \& Hakimi, A. (2020). How multiple large shareholders affect bank profitability under the dispersion and the coalition hypotheses? An insight from the MENA region. International Journal of Managerial Finance, ahead-of-p(ahead-of-print). https://doi.org/10.1108/IJMF-05-2019-0201

Chen, K. (2020). The effects of marketing on commercial banks' operating businesses and profitability: evidence from US bank holding companies. International Journal of Bank Marketing, 38(5), 1059-1079. https://doi.org/10.1108/IJBM-08-2019-0301

Dang, D., \& Vong, J. (2020). Revisiting bank profitability, performance and stability in Asia Pacific (2012-2018) using the EAGLES framework. International Journal of Electronic Finance, 10(1-2), 116-130.

Dietrich, A. and Wanzenried, G. (2011). Determinants of bank profitability before and during the crisis: Evidence from Switzerland. Journal of International Financial Markets, Institutions and Money, 21(3), 307-327. https://doi.org/10.1016/j.intfin.2010.11.002

Dinc, Y. (2018). The Effect of Retail Loans on Bank Profitability: A Comparative Empirical Analysis. Turkish Journal of Islamic Economics, 5(1), 19-34. https://doi.org/10.26414/tujise.2018.5.1.19-34

Dogan, B., \& Eksi, I. (2020). The effect of board of directors characteristics on risk and bank performance: Evidence from Turkey. Economic and Business Review, 6(3), 88-104. https://doi.org/10.18559/ebr.2020.3.5

Doku, J. N., Kpekpena, F. A., \& Boateng, P. Y. (2019). Capital Structure and Bank Performance: Empirical Evidence from Ghana. African Development Review, 31(1), 15-27.

Domanovic, V., Todorovic, V., \& Savovic, S. (2018). Internal factors of bank profitability in the Republic of Serbia. Business and Economic Horizons, 14(3), 659-673. https://doi.org/10.15208/beh.2018.46

Duho, K. C. T., Onumah, J. M., Owodo, R. A., Asare, E. T., \& Onumah, R. M. (2020). Bank risk, profit efficiency and profitability in a frontier market. Journal of Economic and Administrative Sciences, ahead-of-p(ahead-ofprint). https://doi.org/10.1108/JEAS-01-2019-0009

Elsas, R., Hackethal, A., \& Holzhäuser, M. (2010). The anatomy of bank diversification. Journal of Banking \& Finance, 34(6), 1274-1287. https://doi.org/10.1016/j.jbankfin.2009.11.024

Fang, J., Lau, C. K. M., Lu, Z., Tan, Y., \& Zhang, H. (2019). Bank performance in China: A Perspective from Bank efficiency, risk-taking and market competition. Pacific-Basin Finance Journal, 56, 290-309.

Fouche, C. H., Mukuddem-Petersen, J., Petersen, M. A., \& Senosi, M. C. (2008). Bank Valuation and Its Connections with the Subprime Mortgage Crisis and Basel II Capital Accord. Discrete Dynamics in Nature and Society, 2008, 1-44. https://doi.org/10.1155/2008/740845

Gupta, N., \& Mahakud, J. (2020). Ownership, bank size, capitalisation and bank performance: Evidence from India. Cogent Economics \& Finance, 8(1). https://doi.org/10.1080/23322039.2020.1808282

Hamdi, H., Hakimi, A., \& Zaghdoudi, K. (2017). Diversification, bank performance and risk: have Tunisian banks adopted the new business model? Financial Innovation, 3(1), 22. https://doi.org/10.1186/s40854-017-0069-6

Haris, M., Yao, H., Tariq, G., Javaid, H. M., \& Ain, Q. U. (2019). Corporate governance, political connections, and bank performance. International Journal of Financial Studies, 7(4), 62. https://doi.org/10.3390/ijfs7040062

Jegede, C. A. (2014). Effects of Automated Teller Machine on the Performance of Nigerian Banks. American Journal of Applied Mathematics and Statistics, 2(1), 40-46. https://doi.org/10.12691/ajams-2-1-7

Keliuotytè-Staniulėnienè, G., \& Smolskytè, G. (2019). Possibilities for Financial Technology Sector Development and its Impact on Banking Sector Profitability in Lithuania. Economics and Culture, 16(1), 12-23. https://doi.org/ 10.2478/jec-2019-0002 
Królikowska, E., \& Sierpińska-Sawicz, A. (2016). The Types of Covenants in Bond Issuance Programs of Mining Industry Companies. Gospodarka Surowcami Mineralnymi, 32(2), 135-152. https://doi.org/10.1515/gospo-20160014

Le, T. D., \& Ngo, T. (2020). The determinants of bank profitability: A cross-country analysis. Central Bank Review, 20(2), 65-73. https://doi.org/10.1016/j.cbrev.2020.04.001

Naruševičius, L. (2017). Bank Profitability and Macroeconomy: Evidence from Lithuania. Technological and Economic Development of Economy, 24(2), 383-405. https://doi.org/10.3846/20294913.2016.1213192

Ndlovu, C., \& Alagidede, P. (2018). Industry structure, macroeconomic fundamentals and return on equity. International Journal of Emerging Markets, 13(6), 2047-2066. https://doi.org/10.1108/IJoEM-06-2017-0210

Neerza, N., \& Tripathi, V. (2019). Determinants of private equity investment across sectors in India. Journal of Advances in Management Research, JAMR-09-2018-0083. https://doi.org/10.1108/JAMR-09-2018-0083

Neves, M. E. D., Gouveia, M. D. C., \& Proença, C. A. N. (2020). European Bank's Performance and Efficiency. Journal of Risk and Financial Management, 13(4), 67. https://doi.org/10.3390/jrfm13040067

Onay, C., Öztaş, Y. E., Oztas, Y. E., \& Onay, C. (2018). Why Banks Adopt Mobile Banking? The Case of Turkey. International Journal of Electronic Finance, 9(2), 95. https://doi.org/10.1504/IJEF.2018.10011297

Owusu, F. B., \& Alhassan, A. L. (2020). Management and bank profitability: Statistical cost accounting analysis from an emerging market. International Journal of Finance \& Economics, ijfe.1860. https://doi.org/10.1002/ijfe.1860

Ramila, M., \& Gurusamy, S. (2016). Impact of Green Banking Initiatives Adopted by Foreign Banks on Profitability. JIMS8M: The Journal of Indian Management \& Strategy, 21(1), 12. https://doi.org/10.5958/09739343.2016.00002.8

Salimi, S. A., Moshref Javadi, H., \& Ansari, R. (2013). Analysing the impact of electronic banking (ATM and POS devices) on profitability of eight Iranian Banks. Advances in Environmental Biology, 7(8), 1816-1821.

Titko, J., Stankevičienè, J., \& Lāce, N. (2014). Measuring Bank Efficiency: DEA Approach. Technological and Economic Development of Economy, 20(4), 739-757. https://doi.org/10.3846/20294913.2014.984255

Titko, J., Skvarciany, V., Jurevičiene, D. (2016). Drivers of Bank Profitability: Case of Latvia and Lithuania // Intellectual Economics, Vol. 9, Issue 2, pp. 120-129. http://dx.doi.org/10.1016/j.intele.2016.02.003

Turkoglu, D. C., \& Genevois, M. E. (2017). An Analytical Approach for Evaluation of ATM Deployment Problem Criteria. International Journal of Information Technology \& Decision Making, 16(05), 1247-1278. https://doi.org/10.1142/S0219622017500249

Utomo, M. L., \& Anggono, A. H. (2020). Bank Specific Determinants of Bank Profitability in Indonesia for The Period 2008-2019. Jurnal Ilmu Sosial Politik Dan Humaniora, 3(2), 13-21.

Yang, Z., Gan, C., \& Li, Z. (2019). Role of bank regulation on bank performance: Evidence from Asia-Pacific commercial banks. Journal of Risk and Financial Management, 12(3), 131. https://doi.org/10.3390/jrfm12030131 